Article

\title{
Design and Construction of an Effective Expression System with Aldehyde Tag for Site-Specific Enzyme Immobilization
}

\author{
Fang Wang ${ }^{1}$, Rong Li ${ }^{1,2}$, Hui Jian ${ }^{1}$, Zihao Huang ${ }^{1}$, Yingwu Wang ${ }^{1, *}$, Zheng Guo ${ }^{2, *}$ and \\ Renjun Gao ${ }^{1, *(\mathbb{D})}$ \\ 1 Key Laboratory for Molecular Enzymology and Engineering, The Ministry of Education, School of Life \\ Science, Jilin University, Changchun 130021, China; wangfang261621@163.com (F.W.); \\ ryong_li@163.com (R.L.); jianhui4633@163.com (H.J.); huangzh150608@163.com (Z.H.) \\ 2 Department of Engineering, Faculty of Science and Technology, Aarhus University, Gustav Wied Vej 10, \\ 8000 Aarhus, Denmark \\ * Correspondence: wyw@jlu.edu.cn (Y.W.); guo@eng.au.dk (Z.G.); gaorj@jlu.edu.cn (R.G.)
}

Received: 15 March 2020; Accepted: 7 April 2020; Published: 8 April 2020

\begin{abstract}
In recent years, the development and application of site-specific immobilization technology for proteins have undergone significant advances, which avoids the unwanted and random covalent linkage between the support and active site of protein in the covalent immobilization. Formylglycine generating enzyme (FGE) can transform the cysteine from a conversed 6-amino-acid sequence CXPXR into formylglycine with an aldehyde group (also termed as "aldehyde tag"). Based on the frame of pET-28a, the His-tags were replaced with aldehyde tags. Afterward, a set of plasmids were constructed for site-specific covalent immobilization, their His-tags were knock out (DH), or were replaced at different positions: N-terminal (NQ), C-terminal (CQ), or both (DQ) respectively. Three different enzymes, thermophilic acyl aminopeptidase (EC 3.4.19.1) from Sulfolobus tokodaii (ST0779), thermophilic dehalogenase (EC 3.8.1.2) from Sulfolobus tokodaii (ST2570), and Lipase A (EC 3.1.1.3) from Bacillus subtilis (BsLA) were chosen as model enzymes to connect with these plasmid systems. The results showed that different aldehyde-tagged enzymes can be successfully covalently attached to different carriers modified with an amino group, proving the universality of the method. The new immobilized enzyme also presented better thermostability and reutilization than those of the free enzyme.
\end{abstract}

Keywords: aldehyde tag; specific-site; formylglycine generating enzyme; covalent immobilization

\section{Introduction}

Enzyme immobilization is an effective method for stabilizing and improving the efficiency of enzyme utilization. Immobilized enzymes are widely used in biosensors, diagnostics, drug screening, and other fields due to its excellent green, economical, and sustainable properties [1,2]. In recent years, many researchers have concentrated on immobilization as an engineering implement to modulate and improve many of the catalytic properties of enzymes. Therefore, a proper immobilization method is required to improve diverse enzymatic properties such as stability, reutilization, specificity, and selectivity [3-5].

Enzyme immobilization can be achieved by methods such as embedding, cross-linking, physical adsorption, and covalent bonding, according to the nature and application of the enzyme [6,7]. Cross-linking is an irreversible and carrierless immobilization method that exploits the bifunctional reagent to cross-link the enzyme aggregates (CLEAs) [8]. However, CLEAs cannot be widely used in many industrial applications as they lack mechanical resistance [9]. Adsorption has the disadvantages 
that enzymes can easily be removed from the carrier due to the weak non-specific forces such as van der Waals, hydrophobic interactions, and hydrogen bonds $[10,11]$. Compared with these methods, covalent bonding provides a strong link between the enzyme and its carrier, inhibiting enzyme loss into the reaction environment. This method also increases the reutilization, half-life, and thermal stability of the immobilized enzyme [12,13]. However, conventional covalent immobilization has a limitation that causes unoriented attachment of the enzyme to the carrier. In addition, the process of nonspecific reactions may cause denaturation or inactivation during surface immobilization if the functional group locates in or near the active site of proteins [14-16]. Thus, many studies have recognized the significance of the selective immobilization of enzymes and site-specific modifications with an appropriate orientational control on the support surface [17].

One of the advantages of site-specific modification is that a defined covalent bond can be formed between the protein and the material, which ensures uniform distribution of the proteins and accessibility of the active center [18]. Furthermore, the reaction conditions are mild, and the denaturation of proteins is avoided. Therefore, site-specific modification has been used in labeling and oriented protein immobilization to improve availability in structure-function studies and in the application of biosensors [19]. The early method of protein modification was to react with an excess of thiol or amine group reagents by utilizing the reactivity of cysteine and lysine residues to achieve functionalization of the protein. Transamination [20] and periodate oxidation [21] can introduce an aldehyde or a ketone moiety at the $\mathrm{N}$-terminal, which are also common chemical methods for protein modifications. The functional groups of these labels are inert not only in biological media, but also in proteins or other macromolecules, thus enable chemo-selective reaction. Rush et al. [22] reported that a formylglycine generating enzyme (FGE) can convert the cysteine from a conversed sequence CXPXR (aldehyde tag) to a formylglycine with an aldehyde group. Therefore, FGE and aldehyde tag have emerged as power implements for site-specific protein modification and have been widely used in many fields [23]. Wang et al. ligated an aldehyde tag into the $C$ terminal of lipase for covalent immobilization of this enzyme [24]. Carrico et al. introduced aldehyde groups into recombinant proteins using the 6-amino acid sequence recognized by the FGE for the application of protein labeling [25]. These studies also provide an effective protocol for the functionalization of protein at the gene level. Other researchers have reported that they introduced the peptide sequence recognized by FGE into heterologous proteins for site-specific modification of membrane proteins and cytoplasmic proteins in mammalian cells $[26,27]$. In this study, we used this system of introducing an aldehyde tag into enzymes for site-specific immobilization.

Based on the preliminary work, we speculated that the aldehyde tag can be introduced to different enzymes for site-specific immobilization. To evaluate this strategy, we constructed a set of recombinant plasmids with an aldehyde tag for the modification of enzymes. Three enzymes were chosen as models. They were thermophilic acyl aminopeptidase (EC 3.4.19.1) from Sulfolobus tokodaii (ST0779), thermophilic dehalogenase (EC 3.8.1.2) from Sulfolobus tokodaii (ST2570) [28], and Lipase A (EC 3.1.1.3) from Bacillus subtilis (BsLA) [29]. Afterward, we covalently linked aldehyde-tagged enzymes to different amino-modified carriers and characterized several properties. In this research, we tried to establish a site-specific immobilization system by covalently linking aldehyde-tagged enzymes to different amino-modified carriers, and explored the universality of this immobilization method.

\section{Results and Discussion}

\subsection{Construction of Recombinant Plasmid with the Aldehyde Tag}

There are two His-tags in multi clone sites (MCS) in the plasmid pET-28a (Figure 1a). The first His-tag of MCS is located between the Nde I and Nco I, and should be removed to avoid affecting the expression of recombinant proteins. Restriction site Nco I was mutated to restriction site Nde I through site-directed mutagenesis. Then, the plasmid pET-28a DH was constructed by removing the first His-tag with the Nde I restriction enzyme and $T_{4}$ ligase (Figure $1 \mathrm{~b}$ ). Therefore, there was no His-tag at 
the N-terminal of the enzyme. The pET-28a NQ was constructed when the first His-tag was replaced with the aldehyde tag by the site-directed mutagenesis (Figure 1c). The pET-28a CQ was constructed when the second His-tag was replaced with the aldehyde tag based on the plasmid 28a DH (Figure 1d). The pET-28a DQ was constructed when both His-tags were replaced with the aldehyde tags (Figure 1e).

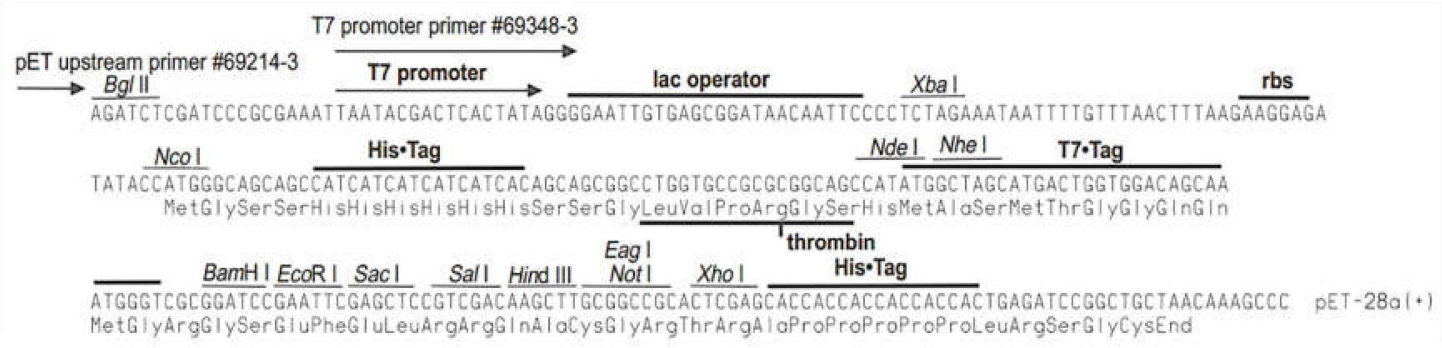

(a)

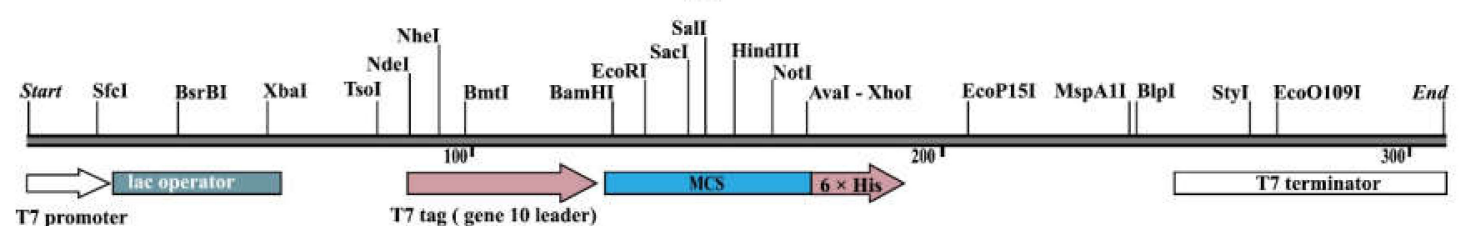

T7 promoter

(b)

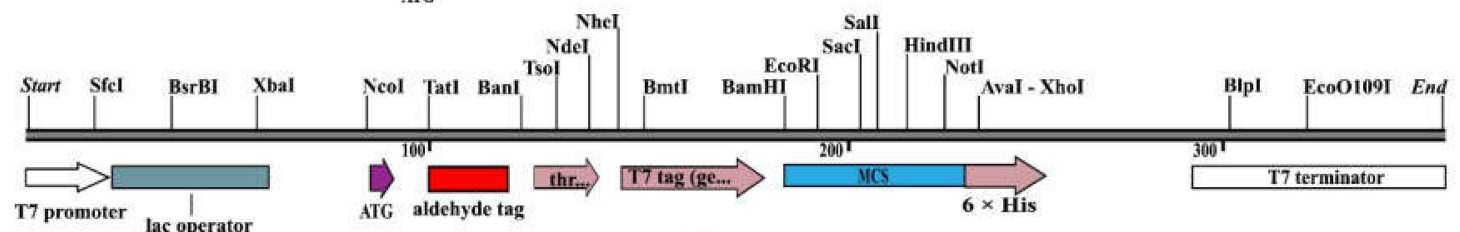

(c)

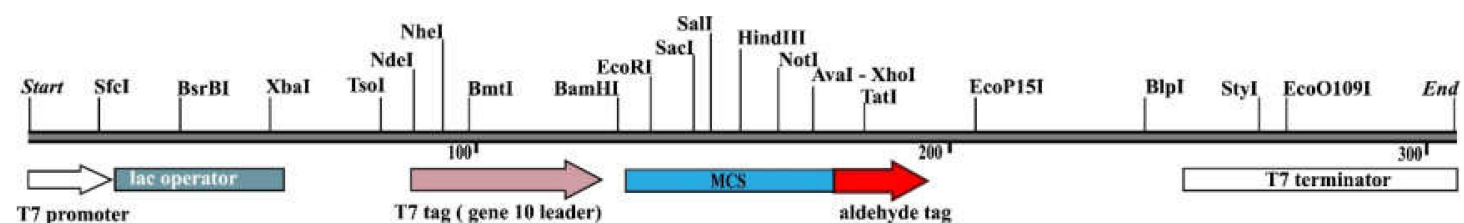

(d)

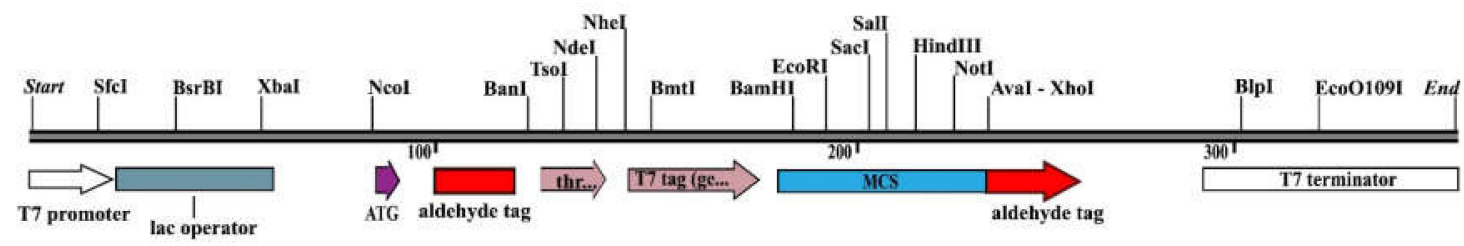

(e)

Figure 1. The plasmid maps. (a) pET-28a cloning region; (b) pET-28a DH cloning region; (c) pET-28a NQ cloning region; (d) pET-28a CQ cloning region; (e) pET28a DQ cloning region.

Generally, the folding and activity of proteins tend to be influenced easily when the exogenous sequence is inserted and expressed at the $\mathrm{N}$-terminal of the natural enzyme [30]. There was a linker between the first His-tag and MCS that was composed of the flexibility amino acid, and could decrease the influence between the exogenous sequence and the natural enzyme [31]. 


\subsection{Expression and Activity Assay of the Recombinant Proteins}

The purpose of new vectors was to establish a standard method for site-specific immobilization, so some different enzymes were selected as models to construct and express aldehyde-tagged enzymes to verify the universality of this method. Three model enzymes including thermophilic acyl aminopeptidase ST0779, thermophilic dichlorination enzyme ST2570, and mesophilic BsLA were chosen, which all belong to the hydrolase family. We chose these three enzymes as templates for their different structures and abilities to hydrolyze various substrates. The crystal structure of ST2570 and BsLA have been resolved, as shown in Figure 2. The monomer of ST2570 contains two domains, a core domain and a subdomain [32,33]. The core domain has a $\beta$-strand surrounded by $\alpha$-helices, and the subdomain is composed of $\alpha$-helices (Figure 2a). The structure of BsLA consists of six $\beta$-strands surrounded by $\alpha$-helices [34] (Figure 2b). ST0779 has a similar and conservative structure with acyl aminopeptidase APE1547 from Aeropyrum pernix K1 (Figure 2c), because both of them belong to the acylamino acid-releasing enzyme. Therefore, we used APE1547 to illustrate the structure of ST0779 [35,36], which contains two different domains, a catalytic domain and a propeller domain. The active site is located between the two domains.

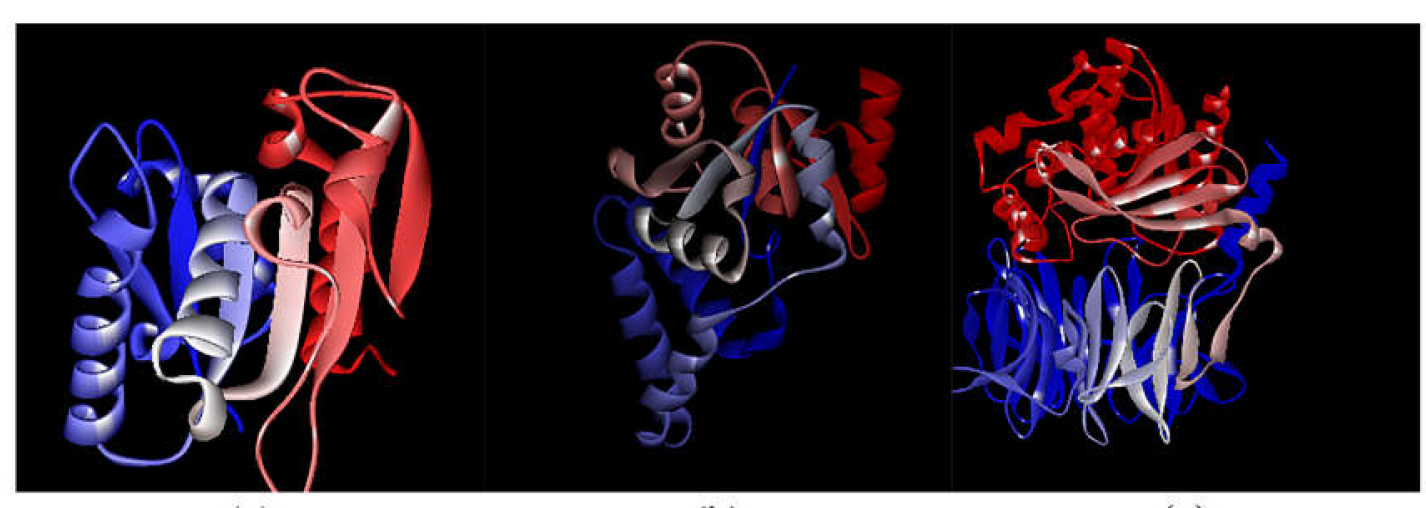

(a)

(b)

(c)

Figure 2. The structure of model enzyme. (a) The structure of ST2570 (PDB:2W43); (b) the structure of BsLA (PDB:1I6W); (c) the structure of APE1547 (PDB:1VE6). The red is the N-terminal and the blue is the C-terminal.

The genes of three model enzymes were inserted into the MCS of different engineered plasmids, respectively. The recombinant plasmids and pBAD-Mtb-FGE plasmid were co-transformed into $E$. coli BL21 (DE3) or E. coli BL21 codon plus (DE3). The model enzymes and formylglycine generating enzyme (FGE) were co-expressed in the E. coli. Afterward, the FGE converted cysteine from the conserved sequence LCTPSR of recombinant enzymes to formylglycine, which allowed the enzymes to carry an aldehyde group at their different terminals (Scheme 1). The expression and activity of model enzymes with aldehyde tags at N, C, or both were detected (Figure 3). The result shows that the expression and activity of enzyme with the aldehyde tag at the C-terminal was higher than that of the N-terminal and the enzyme with aldehyde at both terminals was the lowest in each purified model enzyme. We inferred that the aldehyde tag at the N-terminal might influence the folding and expression of proteins. In addition, the cysteines of an aldehyde tag at both terminals easily formed a disulfide bond with other cysteines of proteins, which might cause the incorrect protein folding. 


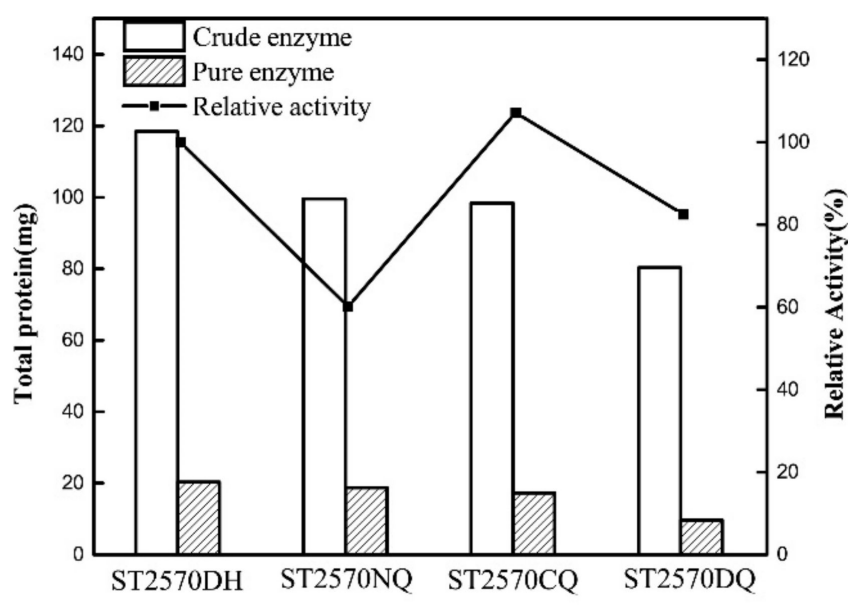

(a)

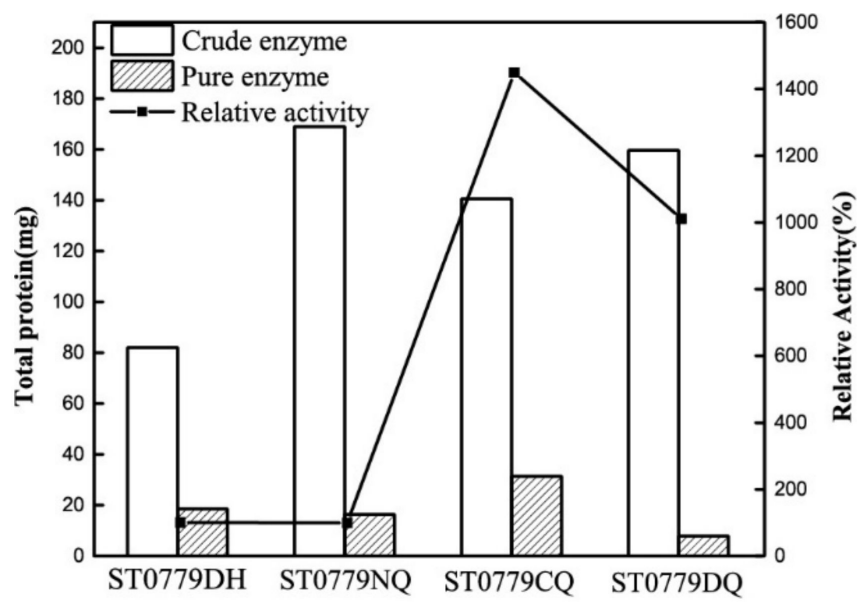

(b)

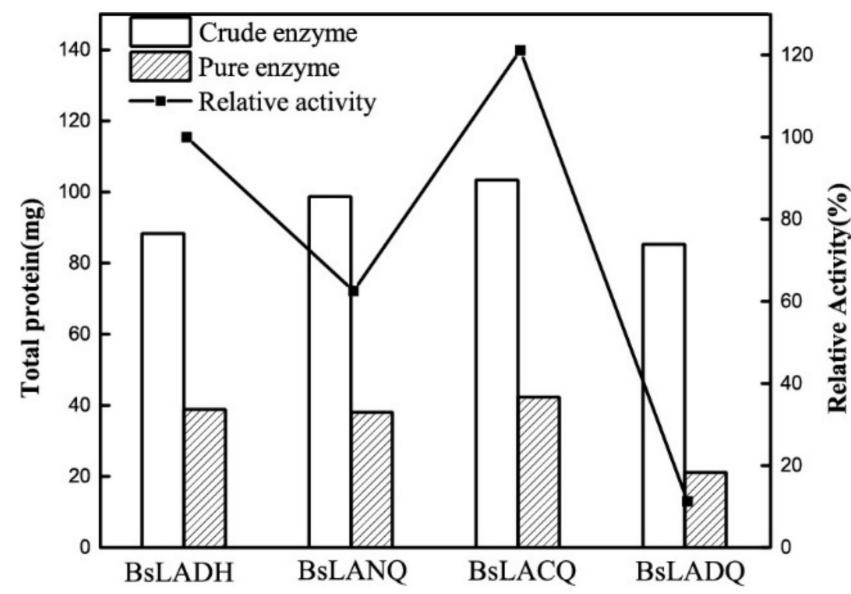

(c)

Figure 3. The expression level and activity of different enzymes. (a) ST2570; (b) ST0779; (c) BsLA. Relativity activity (\%) is the percentage of the DH activity obtained in the series. The DH activity was defined as $100 \%$ relative activity. 


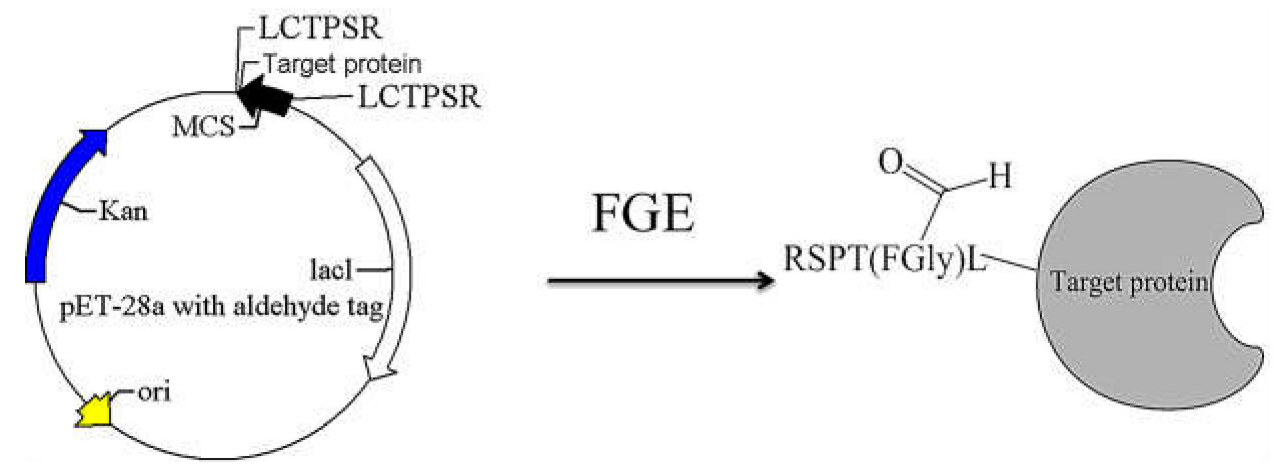

Scheme 1. The aldehyde tag was introduced in the target protein.

\subsection{Identification of Aldehyde Tag}

To validate whether the model enzymes had been successfully modified or not by FGE, the expressed enzymes were reacted with Alexa Fluor 647 C5-aminooxyacetamide (Invitrogen) and were analyzed by sodium dodecyl sulfate polyacrylamide gel electrophoresis (SDS-PAGE) and florescence imaging. The Alexa Fluor 647 C5-aminooxyacatmide came with a fluorescent luminescent group that connected with the aldehyde group. The results show that the enzyme with an aldehyde tag at the C-terminal showed robust labeling, whereas the enzyme with an aldehyde tag at the N-terminal or both terminals did not provide a detectable signal (Figure 4). Compared with ST2570 [28], the fluorescence intensity of ST2570 DQ was much more remarkable than the other two enzymes. We speculate that the aldehyde tag at the N-terminal is encapsulated inside during the folding of the protein, thus the aldehyde tag cannot be captured by the fluorescent group. Moreover, the two cysteines of the aldehyde tag in ST0779DQ or BsLADQ may form the mismatched disulfide bond with other cysteine residues from the proteins. As for ST2570, there was no cysteine residues in the sequence of ST2570 [32], so ST2570DQ showed distinct fluorescence intensity.

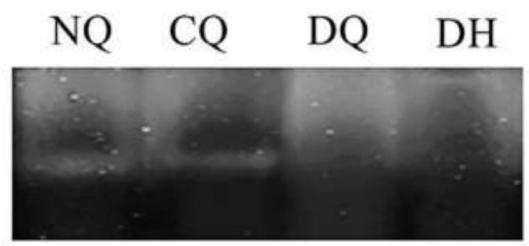

(a)

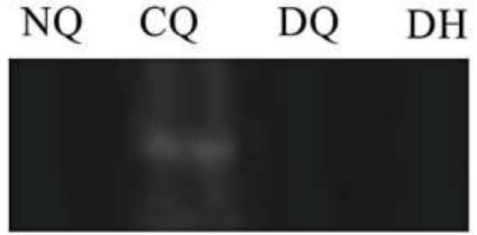

(b)

Figure 4. The aldehyde tagged protein labeled using Alexa Fluor 647. (a) ST0779 with and without an aldehyde tag; (b) BsLA with and without an aldehyde tag.

\subsection{Immobilization Efficiency and Activity Recovery Rate}

In our previous reports, Jian et al. immobilized ST2570 to SBA-15 modified with amino group [28] and Lyu et al. immobilized BsLA to $\mathrm{Fe}_{3} \mathrm{O}_{4}$ magnetic nanoparticles covered with amino-modified $\mathrm{SiO}_{2}\left(\mathrm{SiO}_{2}-\mathrm{Fe}_{3} \mathrm{O}_{4}-\mathrm{NP}\right)$ using this site-specific immobilization method [29]. In order to further confirm the universality of this method for the immobilization of enzymes, we chose styrene anion exchange resin (D380) and $\mathrm{Fe}_{3} \mathrm{O}_{4}$ magnetic nanoparticles as the immobilized carriers. Ion exchange resins are materials widely used in immobilization due to their good capabilities such as uniform pore diameter, porosity, and high surface area [37]. In this context, $\mathrm{Fe}_{3} \mathrm{O}_{4}$ magnetic nanoparticles have been used as the carrier thanks to high surface-volume ratio, their unique magnetic properties, and easy separation by external magnetic field [38,39]. Therefore, ST0779 was immobilized on $\mathrm{SiO}_{2}-\mathrm{Fe}_{3} \mathrm{O}_{4}-\mathrm{NP}$ and ST2570 was immobilized on the styrene anion exchange resin (D380). Then, we measured the properties of the immobilized enzymes. Table 1 [27] shows that the BsLACQ had the maximum immobilization efficiency of over $90 \%$, exhibiting the good loading of BsLA on the carrier. However, the activity 
recovery rate of three immobilized enzymes decreased, which indicated that this immobilization method did not improve enzymic activity. Tables 1 and 2 show that BsLACQ and ST0779CQ had a higher activity recovery rate than that of NQ or DQ. This is because the aldehyde tag at the N-terminal may affect the folding of protein during the initiation of protein synthesis. Furthermore, the two cysteines of the aldehyde tag at both terminals are more likely to mismatch with other cysteines in the proteins, thereby affecting the covalent attachment of the enzyme to the carrier. However, Table 3 shows that ST2570DQ exhibited higher immobilization efficiency and activity recovery rate than the others. This is because the sequence of ST2570 does not contain any cysteine residues. Therefore, the protein cannot form a disulfide bond with the cysteines of the aldehyde tag. It is demonstrated that different model enzymes with an aldehyde tag that are well covalently linked to different carrier materials with amino groups by exploiting the site-specific immobilization method.

Table 1. The activity recovery rate and immobilization efficiency of BsLA immobilized by $\mathrm{SiO}_{2}-\mathrm{Fe}_{3} \mathrm{O}_{4}-\mathrm{NP}$ [29].

\begin{tabular}{ccc}
\hline Immobilized Enzyme & Activity Recovery Rate (\%) & Immobilization Efficiency (\%) \\
\hline BsLACQ & 68.05 & 93.72 \\
BsLANQ & 22.74 & 89.94 \\
BsLADQ & 51.33 & 51.33 \\
\hline
\end{tabular}

Table 2. The activity recovery rate and immobilization efficiency of $\mathrm{ST} 0779$ immobilized by $\mathrm{SiO}_{2}-\mathrm{Fe}_{3} \mathrm{O}_{4}-\mathrm{NP}$.

\begin{tabular}{cccc}
\hline Immobilized Enzyme & Activity (U/g) & Activity Recovery Rate (\%) & Immobilization Efficiency (\%) \\
\hline ST0779CQ & 21.7 & 86.7 & 84.6 \\
ST0779NQ & 16.8 & 38.5 & 82.3 \\
ST0779DQ & 11.1 & 72.9 & 67.7 \\
\hline
\end{tabular}

Table 3. The activity recovery rate and immobilization efficiency of ST2570 immobilized by resin D380.

\begin{tabular}{cccc}
\hline Immobilized Enzyme & Activity (U/g) & Activity Recovery Rate (\%) & Immobilization Efficiency (\%) \\
\hline ST2570CQ & 187.2 & 40.7 & 32.7 \\
ST2570NQ & 105.6 & 25.6 & 13.5 \\
ST2570DQ & 168.9 & 59.9 & 58.9 \\
\hline
\end{tabular}

\subsection{Reutilization of Immobilized Enzyme}

Figure 5 shows the recycling of the immobilized enzyme, which was investigated by hydrolyzing p-nitrophenyl octanoic acid and 2-chloropropionic acid, respectively. The ST2570 immobilized on resin D380 (Figure 5a) retained 40\% activity after eight cycles, and the ST0779 immobilized on $\mathrm{SiO}_{2}-\mathrm{Fe}_{3} \mathrm{O}_{4}-\mathrm{NP}$ (Figure $5 \mathrm{c}$ ) retained $80 \%$ activity after eight cycles. Compared with BsLA immobilized on $\mathrm{SiO}_{2}-\mathrm{Fe}_{3} \mathrm{O}_{4}$-NP (Figure 5d) [29] and ST2570 immobilized on SBA-15 (Figure 5b) [28], BsLA and ST0779 immobilized on $\mathrm{SiO}_{2}-\mathrm{Fe}_{3} \mathrm{O}_{4}-\mathrm{NP}$ could maintain higher activity after eight recycles. However, the activity of ST2570 with resin D380 or SBA-15 as the immobilized carrier decreased significantly after five cycles. We speculate that when using styrene anion exchange resin D380 or SBA-15 as the immobilized carrier, it is necessary to wash repeatedly and separate the immobilized enzyme from the reaction solution by centrifugation after each catalytic reaction. This operation caused the physical loss of the immobilized enzyme, which was manifested as a decrease in the activity of the enzyme. However, the enzymes immobilized on $\mathrm{SiO}_{2}-\mathrm{Fe}_{3} \mathrm{O}_{4}-\mathrm{NP}$ could be very conveniently collected and recovered by a magnet from the reaction system $[40,41]$, which was indicated by less loss of enzyme activity and higher repeated reutilization. 


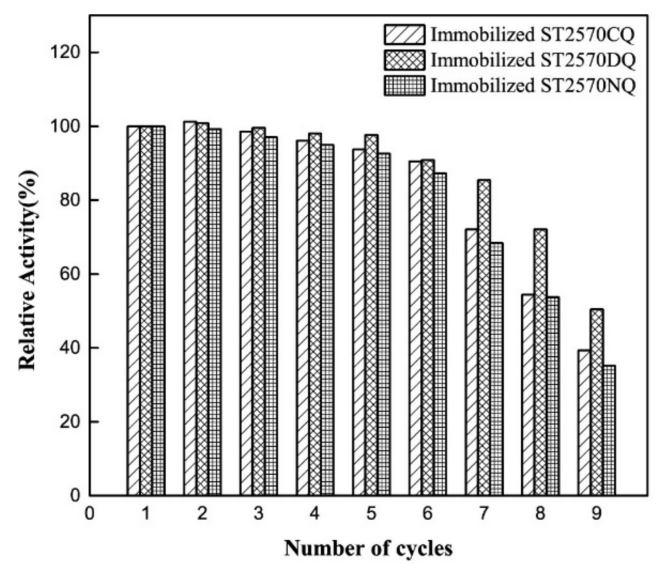

(a)

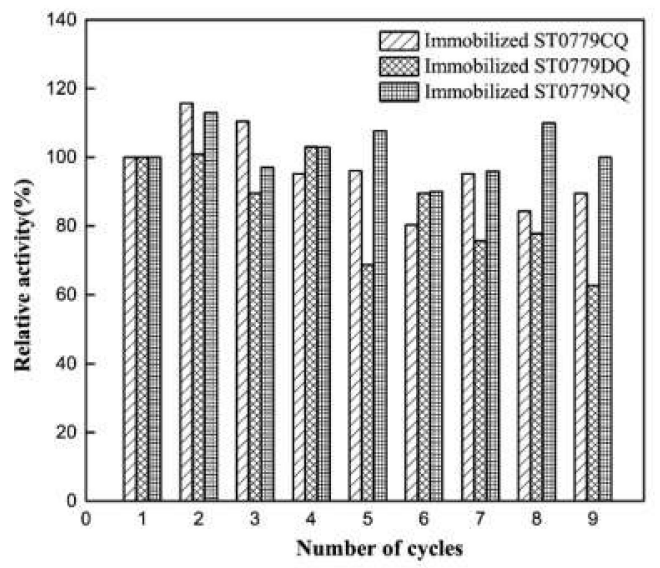

(c)

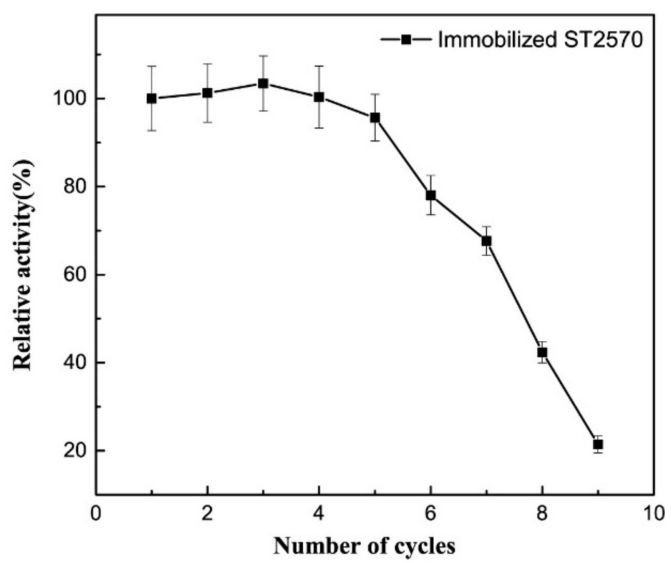

(b)

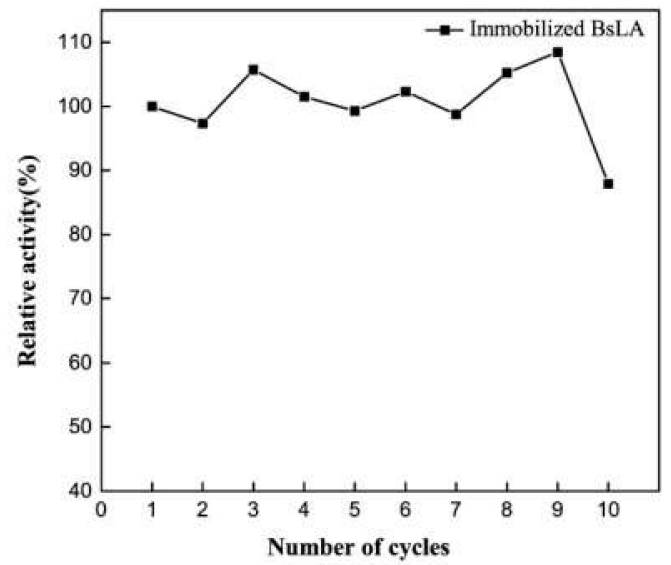

(d)

Figure 5. The reutilization of the immobilized enzyme. (a) The number of reuses of ST2570 immobilized by resin D380; (b) the number of reuses of ST2570 immobilized by SBA-15 [28]; (c) the number of reuses of $\mathrm{ST} 0779$ immobilized by $\mathrm{Fe}_{3} \mathrm{O}_{4}$ covered with $\mathrm{SiO} 2$; (d) the number of reuses of BsLA immobilized by $\mathrm{Fe}_{3} \mathrm{O}_{4}$ covered with $\mathrm{SiO}_{2}$ [29].

\subsection{The Thermostability of Immobilized Enzyme}

Figure 6 indicates the thermostability of the free and immobilized enzymes with aldehyde tags. The thermostability of the immobilized ST2570 (Figure 6a) and ST0779 (Figure 6c) were investigated at $90{ }^{\circ} \mathrm{C}$ and $85{ }^{\circ} \mathrm{C}$. The initial activity was defined as $100 \%$ activity. Compared with our previous reports (Figure $6 \mathrm{~b}, \mathrm{~d}$ ), the activity of all of the free enzymes decreased sharply after $30 \mathrm{~min}$. However, the thermostability of the immobilized enzymes has been significantly improved, which retained approximately $90 \%$ activity after $1 \mathrm{~h}$. This suggests that immobilization of enzymes inhibits the aggregation of molecules after heat treatment, thus preventing the denaturation of model enzymes. Furthermore, the rigid structure of the enzyme can, to some extent, be improved by limiting the flexibility of protein structure with this immobilization method, thus the heat resistance of the enzyme can be enhanced. 


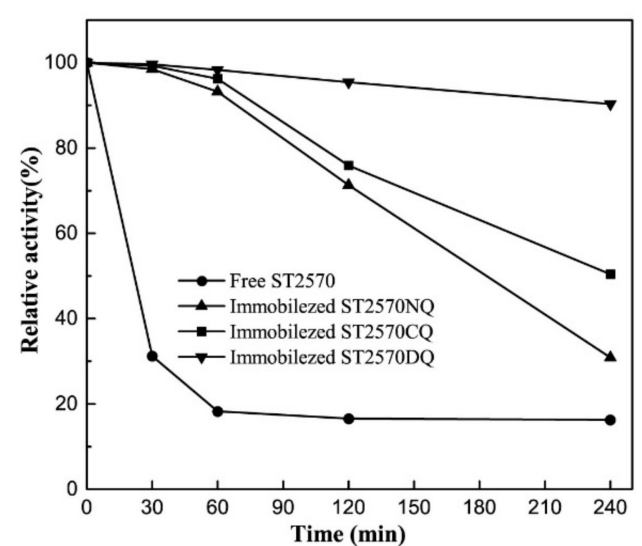

(a)

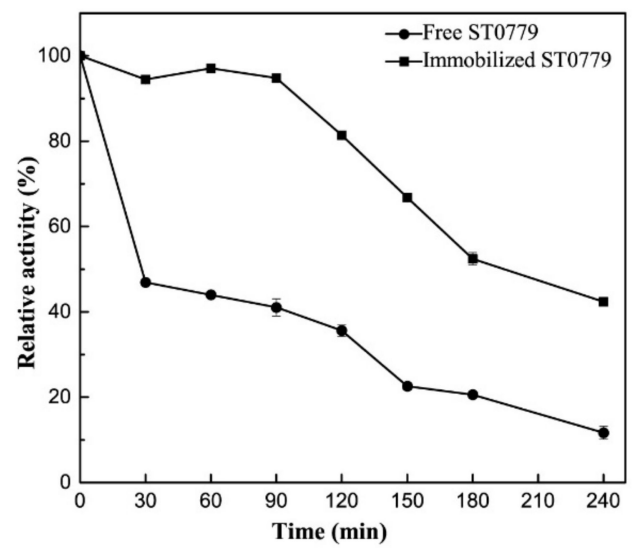

(c)

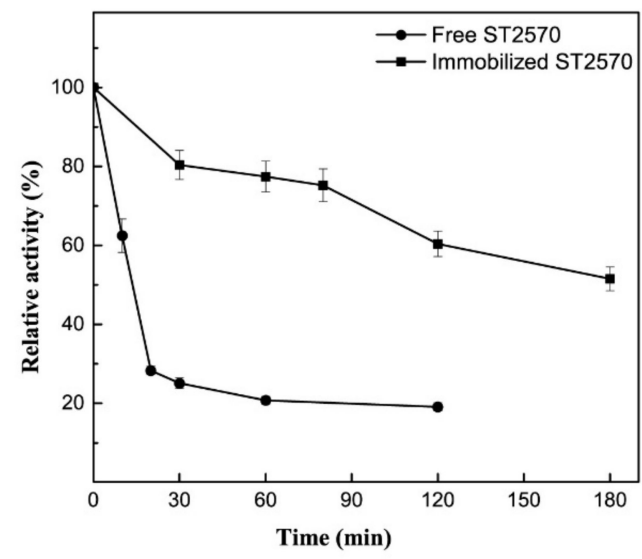

(b)

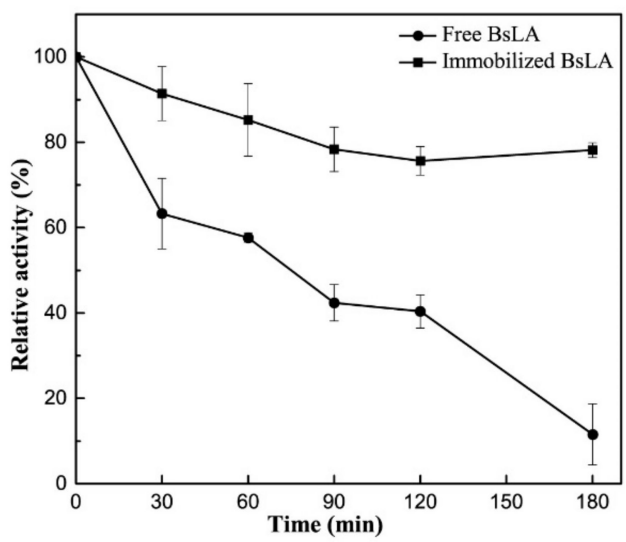

(d)

Figure 6. The thermostability of free and immobilized enzyme. (a) The thermostability of free and immobilized ST2570 by resin D380 at $90{ }^{\circ} \mathrm{C} ;(\mathbf{b})$ the thermostability of free and immobilized ST2570 by SBA- 15 at $90{ }^{\circ} \mathrm{C}$ [28]; (c) the thermostability of free and immobilized ST0779 by $\mathrm{Fe}_{3} \mathrm{O}_{4}$ at $85{ }^{\circ} \mathrm{C}$; (d) the thermostability of free and immobilized BsLA by $\mathrm{Fe}_{3} \mathrm{O}_{4}$ at $50{ }^{\circ} \mathrm{C}$ [29].

\section{Materials and Methods}

\subsection{Materials}

The acyl aminopeptidase (EC 3.4.19.1) ST0779 and dehalogenase (EC 3.8.1.2) ST2570 were cloned from thermophilic archaea Sulfolobus tokodaii (cells of strain 7 T JCM 10545 were obtained from Biological Resource Center, National Institute of Technology and Evaluation, Tokyo, Japan). The Lipase A (EC 3.1.1.3) was cloned from Bacillus subtilis (BsLA). The plasmid pET-28a was bought from Novagen Company (Madisom, WI, USA). The pET-28a-derived plasmids with target proteins were constructed by our laboratory. The primers were synthetized by Sangon Biotech Company (Shanghai, China). Chemicals and other materials used for the expression and purification of all proteins were purchased from Takara Company (Beijing, China), BioTeke Company (Beijing, China), and Sigma Company (St. Louis, MO, USA). The pBAD-M $t b$-FGE plasmid was obtained from a nonprofit plasmid repository (AddGene, Cambridge, mass, MA, USA). The amine functionalized support was styrene anion exchange resin (D380) purchased from The Chemical Plant of NanKai University (Tianjin, China). The magnetic nanomaterial $\mathrm{Fe}_{3} \mathrm{O}_{4}$ covered with $\mathrm{SiO}_{2}$ modified with the amine group was purchased from Beisile (Tianjin, China). 


\subsection{Construction and Transformation of the Recombinant Plasmid with the Aldehyde Tag}

The plasmid pET-28a is often used to express recombinant protein in the laboratory. The primers were designed to replace the His-tag of the plasmid with an aldehyde tag at different locations. Table 4 shows the primers for the site-directed mutagenesis polymerase chain reaction (PCR). The plasmids with the aldehyde tag were constructed by site-directed mutagenesis. PCR products were detected by $0.8 \%$ agarose gel electrophoresis.

Table 4. The detail of site directed mutagenesis primer.

\begin{tabular}{cc}
\hline Name & Primer Sequence $\left(\mathbf{5}^{\prime}\right.$ to $\mathbf{3}^{\prime} \mathbf{)}$ \\
\hline 28aDH up & AGATATCATATGGGCAGCAGCCAT \\
28aDH down & CTGCCCATATGATATCTCCTTCTTAAAG \\
28aNQ up & CAGCCTTTGTACTCCTTCTCGCAGCAGCGGCCTGG \\
28aNQ down & TGCTGCGAGAAGGAGTACAAAGGCTGCTGCCCATGG \\
28aCQ up & CGAGCACTATGTACACCAAGTCGGTAATCCGGCTGCTAAC \\
\hline 28aCQ down & CGGATTACCGACTTGGTGTACATAGTGCTCGAGTGCGGCC \\
\hline
\end{tabular}

\subsection{Expression and Purification of the Recombinant Proteins in E. coli}

The recombinant enzymes were co-expressed by E. coli BL21 codon plus (DE3) cells or E. coli BL21 (DE3) cell with the pBAD-Mtb-FGE plasmid and incubated in LB media with kanamycin, ampicillin, and chloramphenicol, and were shaken at $37^{\circ} \mathrm{C}$ up to an optical density at $600 \mathrm{~nm}\left(\mathrm{OD}_{600}\right)$ up to 0.8 . The expression of FGE was induced with $0.2 \% \mathrm{~L}$-arabinose and incubated at $37^{\circ} \mathrm{C}$ for $30 \mathrm{~min}$. Afterward, the enzymes with the aldehyde tag were induced with $0.5 \mathrm{mM}$ isopropyl $\beta$-D-thiogalactoside (IPTG) and were incubated at $16^{\circ} \mathrm{C}$ for $12 \mathrm{~h}$.

The induced cells were collected by centrifugation at $4000 \mathrm{rpm}$ for $30 \mathrm{~min}$ at $4{ }^{\circ} \mathrm{C}$. The cells of ST0779 [42], ST2570, and BsLA were resuspended, respectively, in 10 volumes of $50 \mathrm{mM}$ Tris- $\mathrm{HCl}$ buffer ( $\mathrm{pH} 8.0), 50 \mathrm{mM}$ sodium phosphate buffer ( $\mathrm{pH}$ 6.0), and $50 \mathrm{mM}$ sodium phosphate buffer ( $\mathrm{pH}$ 7.0). The cells were sonicated until the bacterial solution was no longer viscous. The sonicated bacteria solution was centrifuged at $12,000 \mathrm{rpm}$ for $20 \mathrm{~min}$ at $4{ }^{\circ} \mathrm{C}$, and the supernatants were retained. The supernatants of ST0779 and ST2570 were incubated at $70{ }^{\circ} \mathrm{C}$ for $30 \mathrm{~min}$ to remove the contaminated protein by heat treatment. Discarded deformed protein precipitates by centrifugation at 10,000 rpm for $20 \mathrm{~min}$ at $4{ }^{\circ} \mathrm{C}$, retaining the supernatants. The supernatant of BsLA was added to a $45 \%$ ammonium sulfate solution to remove impure proteins and the supernatant was collected by centrifugation at $10,000 \mathrm{rpm}$ for $20 \mathrm{~min}$ at $4{ }^{\circ} \mathrm{C}$.

\subsection{Examination of the Genetically Encoded Aldehyde Tag Using Reporter Labeling}

Fluorescent labeling reactions were performed by treating $10 \mu \mathrm{g}$ of the target protein with $300 \mu \mathrm{M}$ aminooxy dye (Alexa Fluor 647 C5-aminooxyacetamide, Invitrogen, Carlsbad, CA, USA) in labeling buffer (100 mM PB pH 6.0, $1 \%$ sodium dodecyl sulfate) at $37^{\circ} \mathrm{C}$ for $2 \mathrm{~h}$. Reaction mixtures were separated by SDS-PAGE, and fluorescence was detected collected by Odyssey Infrared Imaging Systems.

\subsection{Enzyme Assay}

The activity of ST0779 was determined in a $1 \mathrm{~mL}$ reaction system: based on the hydrolysis of $p$-nitrophenyl octanoic acid ( $p$-NPC), the mixture was composed of $0.2 \mathrm{mM}$ substrate and $0.2 \mathrm{mg}$ enzyme in the Tris- $\mathrm{HCl}$ buffer $(50 \mathrm{mM}, \mathrm{pH} 8.0)$. The enzyme reaction mixture was incubated at $70{ }^{\circ} \mathrm{C}$ for $2 \mathrm{~min}$, and the $p$-nitrophenol product was quantified spectrophotometrically at $420 \mathrm{~nm}$. One unit was defined as the amount of enzyme that produced $1 \mu \mathrm{mol}$ of $p$-nitrophenol per min.

The activity of BsLA was detected in $1 \mathrm{~mL}$ volume containing $10 \mathrm{mM} p$-NPC, $20 \mathrm{mM}$ phosphate buffer ( $\mathrm{pH}$ 8.0), and rational enzyme solution at $42{ }^{\circ} \mathrm{C}$. This assay was performed by measuring the 
increase in the absorbance at $420 \mathrm{~nm}$ produced by the release of $p$-nitrophenol. One lipase activity unit was defined as the amount of enzyme required to liberate $1 \mu \mathrm{mol}$ of $p$-nitrophenol per minute [19].

The activity of ST2570 was determined in $3 \mathrm{~mL}$ reaction system: $50 \mathrm{mM}$ Gly-NaOH buffer (pH 9.5) and $1 \mathrm{mM}$ (S) 2-chloropropionic acid. The reaction mixture was incubated at $70{ }^{\circ} \mathrm{C}$ for $5 \mathrm{~min}$, and 30 $\mu \mathrm{g}$ enzyme (ST2570) was added for further incubation at $70^{\circ} \mathrm{C}$ for $5 \mathrm{~min}$ and shaken at $110 \mathrm{rpm}$. The reaction was terminated by adding $50 \mu \mathrm{L}$ of $1 \mathrm{M}$ sulfuric acid. After cooling, the system was treated with $2 \mathrm{~mL}$ of $6 \%$ ammonium ferric sulfate solution and $1 \mathrm{~mL}$ of $0.4 \%$ mercury thiocyanate solution to produce the color reaction. The $\mathrm{OD}_{460}$ value of each sample was measured by a spectrophotometer. Enzyme activity unit was defined as the amount of enzyme required to produce $1 \mu \mathrm{mol}$ of chloride per min.

\subsection{Covalent Immobilization}

The amino-functionalized resin D380 (5 mg) was washed with $30 \mathrm{~mL}$ of phosphate buffer (50 $\mathrm{mM}, \mathrm{pH}$ 7.0), and was incubated with ST2570 protein solvent at $16^{\circ} \mathrm{C}$ for $6 \mathrm{~h}$ with shaking at $120 \mathrm{rpm}$. The formed Schiff bases were reduced by using $\mathrm{NaCNBH}_{3}$. The immobilized enzyme was washed three times with $1 \mathrm{M} \mathrm{NaCl}$ solution and phosphate buffer. The enzyme without an aldehyde tag and non-covalent immobilized enzyme were easily eluted using a $1 \mathrm{M} \mathrm{NaCl}$ solution. The immobilized enzyme was separated by using centrifugation at 12,000 rpm for $10 \mathrm{~min}$ and was washed with phosphate buffer until no enzyme activity could be detected in the supernatant. The amount of protein in the supernatant was measured using the Braford assay. The activity of immobilized enzyme was detected by the method mentioned in Section 3.5.

The amino-functionalized $\mathrm{Fe}_{3} \mathrm{O}_{4}$ magnetic nanoparticles covered with $\mathrm{SiO}_{2}(5 \mathrm{mg})$ was washed with deionized water and Tris-HCl buffer ( $\mathrm{pH} 8.0)$. The carrier nanoparticles in the ST0779 solution were mixed and shaken at $10{ }^{\circ} \mathrm{C}$ for $6 \mathrm{~h}$ and were reduced with $2 \%(\mathrm{w} / \mathrm{w}) \mathrm{NaCNBH}_{3}$ for $1 \mathrm{~h}$. The immobilized enzyme was collected by a magnet and washed with $1 \mathrm{M} \mathrm{NaCl}$, saturated $\left(\mathrm{NH}_{4}\right)_{2} \mathrm{SO}_{4}$, and deionized water. The supernatant was used to determine the efficiency of immobilization using an BCA Protein Assay Kit. The activity of immobilized enzyme was detected by the method mentioned in Section 3.5.

Immobilization efficiency $=$ (the concentration of initial enzyme - the concentration of immobilized enzyme)/the concentration of initial enzyme $\times 100 \%$

Activity recovery rate $=$ the activity of immobilized enzyme/the activity of initial enzyme $\times 100 \%$

\subsection{The Reutilization and Thermostability of Immobilized Enzyme}

The immobilized enzyme was collected after each reaction, washed twice with deionized water, and utilized in the next cycle. One cycle reaction of immobilized ST2570 and ST0779 was 5 min and 2 min, respectively. The recycling stability of the immobilized enzyme was evaluated by measuring the relative hydrolyzing activity. The initial activity of the immobilized enzyme was defined as $100 \%$ relative activity.

The thermostability of immobilized ST2570 and ST0779 were incubated at $90{ }^{\circ} \mathrm{C}$ and $85{ }^{\circ} \mathrm{C}$, respectively. All samples were incubated in a heat block with a heat cover. A sample was taken every $30 \mathrm{~min}$ until the relative activity of free enzyme was less than $10 \%$. The activities of the immobilized and free ST2570, ST0779, and BsLA were assayed by the hydrolysis of 2-chloropropionic acid and $p$-nitrophenyl propionic acid.

\section{Conclusions}

In summary, we established an aldehyde-tagged enzyme expression system for one-step covalent and site-specific immobilization. The study showed that three aldehyde-tagged enzymes were successfully immobilized on different amino functionalized supports, and the highest immobilization efficiency of the model enzyme was over $90 \%$, which indicated the universality of the site-specific immobilization. In addition, the reutilization of the immobilized enzyme was higher than that of the 
free enzyme, which verified that the covalent immobilization would prevent the enzyme release into the reaction solution compared with other methods [43]. This is beneficial for the efficient recovery and reuse of enzymes, which also increases the possibility of application in a continuous fixed-bed operation [44,45]. $\mathrm{Fe}_{3} \mathrm{O}_{4}$ magnetic nanoparticles were considered to be an ideal immobilization carrier when compared with others in this study because of its excellent reutilization. The thermostability of the immobilized enzyme increased approximately 3-fold than that of the free enzyme, which indicated that covalent immobilization efficiently improved the stability of the enzyme. These results display that this expression system and immobilization method may become a potential protocol for industrial application.

Author Contributions: Conceptualization, R.G., R.L., and Z.G.; Formal analysis, H.J. and Y.W.; Investigation, F.W., R.L., and H.J.; Writing — original draft preparation, F.W. and R.L.; Writing—review and editing, R.G. and Z.H.; Supervision, R.G., Y.W., and Z.G. All authors have read and agreed to the published version of the manuscript.

Funding: The current work was supported by the National Natural Science Foundation of China (Grant no. 21778021).

Conflicts of Interest: The authors declare no conflicts of interest.

\section{References}

1. Bilal, M.; Asgher, M.; Parra-Saldivar, R. Immobilized ligninolytic enzymes: An innovative and environmental responsive technology to tackle dye-based industrial pollutants-A review. Sci Total Environ. 2017, 576, 646-659. [CrossRef] [PubMed]

2. Bilal, M.; Iqbal, H.M.N.; Shuqi, G. State-of-the-art protein engineering approaches using biological macromolecules: A review from immobilization to implementation view point. Int. J. Biol. Macromol. 2018, 108, 893-901. [CrossRef] [PubMed]

3. Dos Santos, J.C.S.; Barbosa, O.; Ortiz, C. Importance of the Support Properties for Immobilization or Purification of Enzymes. Chemcatchem 2015, 7, 2413-2432. [CrossRef]

4. Garcia-Galan, C.; Berenguer-Murcia, A.; Fernandez-Lafuente, R. Potential of Different Enzyme Immobilization Strategies to Improve Enzyme Performance. Adv. Synth. Catal. 2011, 353, 2885-2904. [CrossRef]

5. Sheldon, R.A. Enzyme immobilization: The quest for optimum performance. Adv. Synth. Catal. 2007, 349, 1289-1307. [CrossRef]

6. Sheldon, R.A.; Van Pelt, S. Enzyme immobilisation in biocatalysis: Why, what and how. Chem. Soc. Rev. 2013, 42, 6223-6235. [CrossRef] [PubMed]

7. Cowan, D.A.; Fernandez-Lafuente, R. Enhancing the functional properties of thermophilic enzymes by chemical modification and immobilization, Enzyme Microb. Technol. 2011, 49, 326-346.

8. Sheldon, R.A. Characteristic features and biotechnological applications of cross-linked enzyme aggregates (CLEAs). Appl. Microbiol. Biotechnol. 2011, 92, 467-477. [CrossRef]

9. Cabana, H.; Jones, J.P.; Agathos, S.N. Utilization of cross-linked laccase aggregates in a perfusion basket reactor for the continuous elimination of endocrine-disrupting chemicals. Biotechnol. Bioeng. 2009, 102, 1582-1592. [CrossRef]

10. Subramanian, A.; Woodward, J.; Doktycz, M.J.; Kennel, S.J. Comparison of techniques for enzyme immobilization on silicon supports. Enzyme Microb. Technol. 1999, 24, 26-34. [CrossRef]

11. Brady, D.; Jordaan, J. Advances in enzyme immobilisation. Biotechnol. Lett. 2009, 31, 1639-1650. [CrossRef] [PubMed]

12. Ispas, C.; Sokolov, I.; Andreescu, S. Enzyme-functionalized mesoporous silica for bioanalytical applications. Anal. Bioanal. Chem. 2009, 393, 543-554. [CrossRef] [PubMed]

13. Ovsejevi, K.; Manta, C.; Batista-Viera, F. Reversible covalent immobilization of enzymes via disulfide bonds. Methods Mol. Biol. 2013, 1051, 89-116. [PubMed]

14. Rusmini, F.; Zhong, Z.; Feijen, J. Protein immobilization strategies for protein biochips. Biomacromolecules 2007, 8, 1775-1789. [CrossRef]

15. Nilsson, J.; Ståhl, S.; Lundeberg, J. Affinity fusion strategies for detection, purification, and immobilization of recombinant proteins. Protein Expres. Purif. 1997, 11, 1-16. [CrossRef] 
16. Zakeri, B.; Fierer, J.O.; Celik, E. Peptide tag forming a rapid covalent bond to a protein, through engineering a bacterial adhesin. Proc. Nati. Acad. Sci. USA 2012, 109, 690-697. [CrossRef]

17. Lesaicherre, M.L.; Uttamchandani, M.; Chen, G.Y.J. Developing site-specific immobilization strategies of peptides in a microarray. Bioorg. Med. Chem. Lett. 2002, 12, 2079-2083. [CrossRef]

18. Hernandez, K.; Fernandez-Lafuente, R. Control of protein immobilization: Coupling immobilization and site-directed mutagenesis to improve biocatalyst or biosensor performance. Enzyme Microb. Tech. 2011, 48, 107-122. [CrossRef]

19. Tiefenbrunn, T.K.; Dawson, P.E. Chemoselective ligation techniques: Modern applications of time-honored chemistry. Peptide Sci. 2010, 94, 95-106. [CrossRef]

20. Scheck, R.A.; Dedeo, M.T.; Iavarone, A.T.; Francis, M.B. Optimization of a biomimetic transamination reaction. J. Am. Chem. Soc. 2008, 130, 11762-11770. [CrossRef]

21. Geoghegan, K.F.; Stroh, J.G. Site-directed conjugation of nonpeptide groups to peptides and proteins via periodate oxidation of a 2-amino alcohol. Application to modification at $\mathrm{N}$-terminal serine. Bioconjugate Chem. 1992, 3, 138-146. [CrossRef] [PubMed]

22. Rush, J.S.; Bertozzi, C.R. New Aldehyde Tag Sequences Identified by Screening Formylglycine Generating Enzymes in Vitro and in Vivo. J. Am. Chem. Soc. 2008, 130, 12240-12241. [CrossRef] [PubMed]

23. Peng, Q.; Zang, B.; Zhao, W.; Li, D.; Ren, J.; Ji, F.; Jia, L. Efficient continuous-flow aldehyde tag conversion using immobilized formylglycine generating enzyme. Catal. Sci. Technol. 2020, 10. [CrossRef]

24. Wang, A.; Du, F.; Wang, F.; Shen, Y.; Gao, W.; Zhang, P. Convenient one-step purification and immobilization of lipase using a genetically encoded aldehyde tag. Biochem. Eng. J. 2013, 73, 86-92. [CrossRef]

25. Carrico, I.S.; Carlson, B.L.; Bertozzi, C.R. Introducing genetically encoded aldehydes into proteins. Nat. Chem. Biol. 2007, 3, 321-322. [CrossRef]

26. Wu, P.; Shui, W.; Carlson, B.L.; Hu, N.; Rabuka, D.; Lee, J.; Bertozzi, C.R. Site-specific chemical modification of recombinant proteins produced in mammalian cells by using the genetically encoded aldehyde tag. Proc. Natl. Acad. Sci. USA 2009, 106, 3000-3005. [CrossRef]

27. Rabuka, D.; Rush, J.S.; deHart, G.W.; Wu, P.; Bertozzi, C.R. Site-specific chemical protein conjugation using genetically encoded aldehyde tags. Nat. Protoc. 2012, 7, 1052-1067. [CrossRef]

28. Jian, H.; Wang, Y.; Bai, Y.; Li, R.; Gao, R. Site-specific, covalent immobilization of dehalogenase ST2570 catalyzed by formylglycine-generating enzymes and its application in batch and semi-continuous flow reactors. Molecules 2016, 21, 895. [CrossRef]

29. Lyu, J.; Li, Z.; Men, J. Covalent immobilization of Bacillus subtilis lipase A on $\mathrm{Fe}_{3} \mathrm{O}_{4}$ nanoparticles by aldehyde tag: An ideal immobilization with minimal chemical modification. Process Biochem. 2019, 81, 63-69. [CrossRef]

30. Guimaraes, C.P.; Witte, M.D.; Theile, C.S. Site-specific C-terminal and internal loop labeling of proteins using sortase-mediated reactions. Nat. Protoc. 2013, 8, 1787-1799. [CrossRef]

31. Theile, C.S.; Witte, M.D.; Blom, A.E.M. Site-specific N-terminal labeling of proteins using sortase-mediated reactions. Nat. Protoc. 2013, 8, 1800-1807. [CrossRef] [PubMed]

32. Rye, C.A.; Isupov, M.N.; Lebedev, A.A. Biochemical and structural studies of a L-haloacid dehalogenase from the thermophilic archaeon Sulfolobus tokodaii. Extremophiles 2009, 13, 179-190. [CrossRef] [PubMed]

33. Rye, C.A.; Isupov, M.N.; Lebedev, A.A. An order-disorder twin crystal of 1-2-haloacid dehalogenase from Sulfolobus tokodaii. Acta Crystallogr. D 2007, 63, 926-930. [CrossRef] [PubMed]

34. Van Pouderoyen, G.; Eggert, T.; Jaeger, K.E. The crystal structure of Bacillus subtilis lipase: A minimal alpha/beta hydrolase fold enzyme. J. Mol. Biol. 2001, 309, 215-226. [CrossRef] [PubMed]

35. Bartlam, M.; Wang, G.; Yang, H.; Gao, R.; Zhao, X.; Xie, G. Crystal structure of an acylpeptide hydrolase/esterase from Aeropyrum pernix k1. Structure (Cambridge) 2004, 12, 1481-1488. [CrossRef] [PubMed]

36. Rao, L.; Bi, Y.F.; Xie, G.Q. Study on a specific site tyr444 on a hyperthermophilic enzyme APE1547. Chem. Res. Chin. Univ. 2009, 25, 353-356.

37. Holyavka, M.G.; Kondratyev, M.S.; Lukin, A.N.; Agapov, B.L.; Artyukhov, V.G. Immobilization of inulinase on KU-2 ion-exchange resin matrix. Int. J. Biol. Macromol. 2019, 138, 681-692. [CrossRef]

38. Ahmad, R.; Sardar, M. Enzyme immobilization: An overview on nanoparticles as immobilization matrix, Biochem. Anal. Biochem. 2015, 4, 1-8. 
39. Armenia, I.; Grazú Bonavia, M.V.; De Matteis, L.; Ivanchenko, P.; Martra, G.; Gornati, R.; de la Fuente, J.M.; Bernardini, G. Enzyme activation by alternating magnetic field: Importance of the bioconjugation methodology. J. Colloid. Interface. Sci. 2019, 537, 615-628. [CrossRef]

40. Lu, A.H.; Salabas, E.L.; Schueth, F. Magnetic nanoparticles: Synthesis, protection, functionalization, and application. Angew. Chem. Internat. Ed. 2007, 46, 1222-1244. [CrossRef]

41. Wu, W.; Wu, Z.; Yu, T.; Jiang, C.; Kim, W.S. Recent progress on magnetic iron oxide nanoparticles: Synthesis, surface functional strategies and biomedical applications, Sci. Technol. Adv. Mater. 2015, 16, 023501. [CrossRef] [PubMed]

42. Rong, L.; Fei, Z.; Cao, S.G. Expression and Characterization of a Thermostable Acyl-peptide Releasing Enzyme ST0779 from Sulfolobus tokodaii. Chem. Res. Chin. Univ. 2012, 28, 851-855.

43. Mohamad, N.R.; Marzuki, N.H.C.; Buang, N.A.; Huyop, F.; Wahab, R.A. An overview of technologies for immobilization of enzymes and surface analysis techniques for immobilized enzymes. Biotechnol. Biotec. Eq. 2015, 29, 205-220. [CrossRef] [PubMed]

44. Sheldon, R.A. Cross-linked enzyme aggregates (CLEAs): Stable and recyclable biocatalysts. Biochem. Soc. 2007, 35, 1583-1587. [CrossRef] [PubMed]

45. Tian, X.; Anming, W.; Lifeng, H.; Haifeng, L.; Zhenming, C.; Qiuyan, W.; Xiaopu, Y. Recent advance in the support and technology used in enzyme immobilization. Afr. J. Biotechnol. 2009, 8, 4724-4733.

(C) 2020 by the authors. Licensee MDPI, Basel, Switzerland. This article is an open access article distributed under the terms and conditions of the Creative Commons Attribution (CC BY) license (http://creativecommons.org/licenses/by/4.0/). 